\title{
Rafal Cekiera
}

rafal.cekiera@us.edu.pl

Instytut Socjologii

Uniwersytet Śląski w Katowicach

ORCID: 000-0003-3649-6645

\section{„OCAL LUDZKOŚĆ PRZED KORONAWIRUSEM!" ANALIZA INTERNETOWYCH INTENCJI MODLITEWNYCH W CZASIE PANDEMII}

\section{"Save the mankind from the coronavirus!". Analysis of internet prayer intentions during the times of pandemic.}

Streszczenie: W artykule analizie poddano wpisy na polskich internetowych skrzynkach intencji modlitewnych, dokonane przez orantów podczas pandemii koronawirusa w okresie marzec-kwiecień 2020 roku. Badanie tego specyficznego rodzaju dokumentów osobistych pozwoliło rozpoznać, w jaki sposób ekstraordynaryjna sytuacja egzystencjalna została przefiltrowana przez religijne wyobrażenia i włączona do transcendentnego kontekstu znaczeniowego. Celem analizy była także identyfikacja postrzegania koronawirusa przez zapisujących modlitwy, eksploracja przyjmowanych względem nagłego zagrożenia postaw oraz oszacowanie zakresu wyobrażonej wspólnoty w modlitwach wstawienniczych.

Slowa kluczowe: modlitwa, skrzynki intencji, religia, koronawirus, pandemia

\begin{abstract}
The article analyses the postings delivered to Polish Internet prayer intention boxes that were supplied by orants during the coronavirus pandemic in March-April 2020. The examination of this specific type of personal documents allowed to recognize in what ways this extraordinary existential situation was filtered by religious imaginations and incorporated into a transcendent context of meanings. The aim of the analysis was also to identify the perception of the coronavirus by individuals who recorded the prayers, to explore the attitudes presented amid sudden threat and to estimate the scope of the imagined community in intercessions.
\end{abstract}

Key words: prayer, intention boxes, religion, coronavirus, pandemic 
Niepewność jest pojęciem często goszczącym na łamach publikacji próbujących referować społeczno-kulturowe konteksty ludzkiego życia na początku XXI wieku. Podczas pandemii koronawirusa SARS-CoV-2 awansowało ono na sam szczyt hierarchii słów najbardziej użytecznych i adekwatnych względem niespodzianej, ekstraordynaryjnej rzeczywistości. Wraz z rozprzestrzenianiem się skrytobójczego patogenu życie stało się niepewne na wielu obszarach. Kolejne informacje o wprowadzanych obostrzeniach zmuszały do przyjmowania za oczywiste tego, co jeszcze kilka tygodni wcześniej wydawało się niewyobrażalne. Wirus brutalnie i w sposób nagły wytrącił wiele osób z poczucia ontologicznego bezpieczeństwa. To ono umożliwia nawykowe „odpowiedzi” wobec zasadniczych pytań egzystencjalnych oraz pozwala nie zawracać sobie nimi głowy, umiejętnie je separując od rutyny codzienności (Giddens 2001). „Zaskoczeni znienacka, staliśmy wszyscy bezradni w obliczu klęski, której ogromu ani zmniejszyć, ani nawet w przybliżeniu określić nie byliśmy w stanie. Ogólne uczucie grozy zwiększała niemoc terapii, bezowocność wszystkich wysiłków w przypadkach złośliwych, szybko kończących się śmiercią" - referował doświadczenia związane z pandemią grypy hiszpanki jeden z polskich lekarzy (Rozenfeld 1922). Niemal wiek później słowa te znów brzmią złowrogo aktualnie. Obecną definicję sytuacji zderzenia z zarazą należałoby wszakże uzupełnić przynajmniej o jeden wymiar - jej medialnych przedstawień: rzetelnych informacji, ale i clickbaitowych osobliwości, nierzadko wprowadzających dodatkowy chaos i strach.

Koronawirusowa niepewność wywołuje różnorodne strategie radzenia sobie z tą - przekraczającą wyobraźnię wielu - sytuacją, mające na celu odzyskanie w jak największym stopniu poczucia kontroli nad własnym życiem. Jedną z nich może być złożenie swojego losu w ręce rządowych ekspertów, mających ku temu legitymizowane władzą pełnomocnictwo, i podporządkowywanie się ich wszelkim poradom i sugestiom - z nadzieją, że zapewnią one niezbędny poziom jednostkowego bezpieczeństwa. Procedura ta wymaga głębokiego zaufania względem decydentów. $\mathrm{Na}$ nieufności z kolei ufundowana jest inna strategia, która wyraża się delegitymizacją obowiązujących definicji sytuacji. Wielość rozmaitych teorii spiskowych, których wspólnym funkcjonalnym rdzeniem jest wskazywanie prawdziwego oblicza pandemii, zdaje się zupełnie zrozumiała. Ich natychmiastowy wykwit można traktować jako reakcję na dojmującą potrzebę racjonalizacji sytuacji, próbę jej pojęcia i nadania jej 
sensu. W końcu wyróżnić możemy strategię, która nas będzie interesowała w tym artykule: śladami swoich przodków wiele osób zwróciło się do religijnych źródeł, szukając tam pomocy - ale także interpretacji sytuacji i wpisania jej w szerszy egzystencjalny kontekst.

Odwoływanie się do sfery sacrum w sytuacji niepewności czy zagrożenia jest oczywistym mechanizmem - psychologowie religii zwracają uwagę, że „ludzie często uciekają się do modlitwy wówczas, gdy zakwestionowane zostaje ich poczucie kontroli nad sytuacją" (Ladd, Spilka 2014: 152). To, co człowieka spotyka, zostaje przeniesione przez zinternalizowane wyobrażenia religijne do transcendentnego kontekstu znaczeniowego i „legitymizowane przez »logikę« świętego kosmosu” (Luckmann 1996: 106-107). Nie znosi to nijak utrapień i dolegliwości, ale pozwala nadać im sens. Jak pisał J. Mariański, religia nie uwalnia „człowieka od niepokojów i lęków, od poczucia obcości i samotności, od różnorodnych kryzysów sensu, ale daje szansę włączenia tych wszystkich odczuć w wiarygodne uniwersum aksjologiczne, które nabiera jakby charakteru obiektywnego" (2013: 158). Historia reakcji na niosące śmierć i strach zarazy w poprzednich wiekach może być potwierdzeniem tej funkcji religii. Świetnie ilustrują to słowa jednego z osiemnastowiecznych traktatów, powstałego w czasie epidemii dżumy: „Chrześcijański spokój i akceptacja woli Boga to najlepsze środki, które sprawią, że nikomu włos z głowy nie spadnie, a według których wszystko, także choroba i śmierć będą się jawić jako korzystne" (Behrens 1714, za: Górska 2010: 292).

Wstawiennictwo i pomoc Boga czy świętych przywołuje się w sytuacji beznadziejnej, gdy człowiek z całą bezwzględnością doświadcza swojej ograniczoności, niemożności panowania nad swoim losem (Kowalski 1994: 133). Relację pomiędzy człowiekiem (i jego powinnościami) a Bogiem można interpretować w taki sposób, jak czyni to S. Marai: „Boga można prosić tylko o takie rzeczy, nad którymi nie mamy władzy. Wszystko inne - a więc to, co można osiągnąć wolą - Bóg pozostawił nam” (2017: 462)1. Innym jeszcze źródłem ucieczek „pod Twoją obronę” może być odczytywanie takich zjawisk jak zarazy - czy szerzej choroby i nieszczęścia - jako zesłanej przez Boga kary. W wielu tradycyjnych kulturach chorobę interpretowano jako „symptom nieczystości człowieka”

${ }^{1}$ Ciekawa w tym kontekście jest popularność, którą w ostatnich latach cieszy się modlitwa ks. D. Ruotolo, której motywem przewodnim jest zawołanie „Jezu, Ty się tym zajmij” (np. Bątkiewicz-Brożek 2017). 
(Kowalski 2007: 54). Modlitwa czy składane ofiary mają wówczas na celu pokutę, przebłaganie za nieprawości i odzyskanie przychylności bóstwa.

\section{Wpisy modlitewne jako material badawczy}

W artykule przyjrzymy się specyficznemu gatunkowi modlitwy indywidualnej formułowanej przez samych wiernych, jakim są wpisy orantów zamieszczane w internetowych skrzynkach intencji. Jej charakterystyka stanowi o dużej przydatności badawczej - w modlitwie indywidualnej wybija się na plan pierwszy biegun antropologiczny, ,do Boga (lub innej osoby ze sfery sacrum) mówi konkretny człowiek, a więc wypowiedź bywa wyszukana, bywa też niezborna - dominuje w niej bowiem perspektywa ludzkiej biedy" (Wojtak 2000: 140).

Praźródłem internetowych wpisów modlitewnych są księgi wotywne, tradycyjnie wystawiane w niektórych sanktuariach czy innych uświęconych miejscach. W nich pielgrzymi zapisują swoje prośby czy wyrażają wdzięczność za przypisywane sacrum ingerencje w ich doczesny żywot. Analizując takie dokumenty P. Kowalski zwracał uwagę, że „modlitewny tok wpisów łączy w sobie tradycję, poetykę modlitwy z apelem o interwencję w kształt świata. Tkwi w tym jednak również pamięć o »sprawczej mocy słów«, o skuteczności słownego ingerowania w rzeczywistość” (Kowalski 1994: 38). Z kolei J. Tokarska-Bakir na podstawie własnych badań Księgi łask z Kalwarii Pacławskiej uznaje indywidualne wpisy orantów za ,jedno z najbardziej niezwykłych źródeł”, w którym odzwierciedlają się „nadzieje i pragnienia, a przede wszystkim lę k i współczesnych pielgrzymów" (2000: 117). Zwraca się także uwagę na pewne rozszczepienie, związane z formalną stroną zapisywanych tekstów. Z jednej strony przynależna jest im mowa „euche - język prośby, modlitwy i pragnienia” (Sławek 2013: 99), z drugiej wszakże stają się one intrygującym probierzem ,późnonowoczesnego komunikowania sacrum” (Kapusta, Poźniak, 2011: 58). Taka forma komunikacji może swoimi atrybutami przypominać list (Makuchowska 1998), lecz nade wszystko - być fascynującym zwierciadłem ludzkich spraw, nadziei i zgryzot, także historycznie ważnych w danym momencie. Dość przywołać cytowany przez P. Kowalskiego wpis z 1991 roku - „Boże pomóż zrealizować plan Balcerowicza!” (1993: 52).

Pomiędzy prośbami notowanymi w księgach wotywnych a zapisami $\mathrm{w}$ internetowych skrzynkach modlitewnych istnieje wiele podobieństw. 
Biorąc wszakże pod uwagę fakt, że „komunikat wotywny istnieje jako pewna społeczna sytuacja komunikacyjna" (Kowalski 1993: 26), należy także podkreślić istotne między nimi różnice. Internetowe skrzynki intencji są niewątpliwie łatwiej dostępne - orant ma możliwość dokonania wpisu o dowolnej porze, bez konieczności podejmowania trudu pielgrzymki do naznaczonej cudownością przestrzeni. Ten wysiłek nadaje wszakże odpowiednią rangę i znaczenie wpisowi - może on mieć charakter mniej impulsywny czy przygodny. Przebywając w miejscu z wystawioną księgą wotywną człowiek znajduje się w przestrzeni sakralnej - co samo w sobie jest niezwykle ważnym kontekstem dokonywanej próby komunikacji z Bogiem czy świętymi i sprzyja rozbudzaniu mirakularnej wrażliwości. To miejsce zawsze szczególne - jak pisał S. Czarnowski, „obszar czy też wycinek, wydzielony i otoczony granicą, z chwilą gdy jest wzięty w posiadanie i przydzielony, staje się siedliskiem osobnego kultu, a także warunki życia duchowego kształtują się tam w sposób swoisty" (1939: 5). Internet z kolei może przypominać obszar poza ,terenem życia normalnego", który tenże klasyk polskiej socjologii charakteryzował w sposób następujący: ,nieokreślona dziedzina, domena świętości niezorganizowanej. Srożą się tam moce duchowe nieokiełznane, straszne i zgubne dla tych, którzy ośmieliliby się tam zjawić nieprzygotowani" (Czarnowski 1939: 5-6). W analizach akcentuje się różnice częstotliwości pojawiania się określonych intencji modlitewnych w zapisach tradycyjnych i internetowych - na przykład częstsze odniesienia do relacji międzyludzkich czy pracy w tych drugich (Wilkinson, Althouse 2015: 172-173). Niewielka liczba takich badań porównawczych każe jednak zachować dużą wstrzemięźliwość w formułowaniu kategorycznych wniosków.

O ile dokonanie wpisu modlitewnego w miejscu świętym, do którego się przybyło, sprowokowane obecnością wystawionej tam księgi, wydaje się niejako naturalne - o tyle mniej oczywiste zdaje się zapisywanie własnej modlitwy w przestrzeni wirtualnej. Możemy jednak spróbować zrekonstruować taką komunikacyjną sytuację. Ktoś siedzi przy komputerze czy tablecie, być może gdzieś się przemieszcza, trzymając w ręce smartfon. Jest czymś poruszony, coś go dotyka, odczuwa niepokój. $Z$ jakiegoś powodu nie wystarcza mu wypowiedziana czy wewnętrzna, bezgłośna modlitwa. Niemal natychmiast może wyszukać w Internecie miejsce do jej zapisu, za pomocą klawiszy formułuje jej treść. Przybiera ona materialny kształt, jest widoczna. Orant potwierdza tekst i gotowość do opublikowania poprzez kliknięcie odpowiedniej ikony („Wyślij”). 
Modlitwa została zło żon a - za pomocą internetowych łączy w y s ła n a do Boga lub świętych. Próby rozkodowania tychże zapisów oraz ich interpretacji należy podejmować z dużą starannością, w duchu postulowanej przez J. Tokarską-Bakir „gęstej lektury”. Dzięki niej - podkreśla badaczka-możemy ćwiczyć się w specyficznej egzegetycznej wrażliwości, która pozwala ,z napisu pozostawionego przez wędrowca na wrotach zamku zrozumieć coś więcej niż to, że miał on przy sobie scyzoryk" (2000: 16).

Na potrzeby artykułu przeanalizowane zostały wpisy na trzech internetowych witrynach-skrzynkach intencji: kjb24.pl/ksiega-intencji (podstrona witryny dwumiesięcznika „Któż jak Bóg. Dwumiesięcznik o aniołach i życiu duchowym", propagującej postać św. Michała Archanioła), ogrod. augustianki.pl/intencje (podstrona witryny „Ogród św. Rity. Ku pokrzepieniu serc", prowadzonej przez Siostry Augustianki i szerzącej kult św. Rity, uznawanej za patronkę spraw beznadziejnych) oraz skrzynkaintencji.pl (strona pod opieką Franciszkańskiego Zakonu Świeckich we Wrocławiu). W wielu przypadkach trudno dociec, jaka intencja czy motywacja kryje się za konkretnym wpisem - na przykład prośby „aby wszystko wróciło do normalności” czy o „opiekę w tym trudnym czasie” mogą być powodowane obawami związanymi z epidemią, lecz przecież także dotyczyć innych, indywidualnych doświadczeń petenta. W związku z tym przyjęto kryterium selekcji wpisów do badan oparte o występowanie kilku haseł-kluczy. Analizie poddano wyłącznie wszystkie te zapisy, które zawierały (niezależnie od formy gramatycznej czy błędów językowych) jeden z wymienionych terminów: koronawirus (lub coronawirus), wirus, COVID, epidemia, pandemia, zaraza, zakażenie. W ten sposób wyselekcjonowanych zostało $\mathrm{w}$ sumie 619 poddanych badaniu wpisów, w tym: kjb24.pl/ksiega-intencji - 21 (z łącznej liczby wpisów w analizowanym okresie 141), ogrod.augustianki.pl/intencje - 539 (spośród 2203) oraz skrzynkaintencji.pl - 59 (spośród 532).

Ramę czasową dla selekcji korpusu badawczego wyznaczały daty między 1 marca a 30 kwietnia 2020 r. Okres ten uznać można za początek rozwoju pandemii w Polsce (pierwszy przypadek odnotowano 4 marca 2020 r.) oraz - co jeszcze istotniejsze dla prowadzonych analiz - okres intensywnego wpływu koronawirusa na świadomość społeczną Polaków i wprowadzania związanych $\mathrm{z}$ nim restrykcji. Zanim jeszcze wykryto w Polsce pierwsze zarażenie, w skrzynkach intencji znaleźć można już było prewencyjne wpisy, w których oranci prosili o ochronę przed zbliżającym się zagrożeniem: 
Ocal ludzkość przed koronawirusem! Analiza internetowych...

Święta Rito, proszę Cię aby Coronawirus nie dotarł do Polski i aby Bóg powstrzymał tą epidemie ${ }^{2}$

Proszę o opiekę nad naszym krajem przed zbliżającym się zagrożeniem epidemiologicznym. Chroń nas i nasz kraj przed chorobami i zagrożeniem, czuwaj nad nami ${ }^{3}$.

Dla popularności wpisów na internetowych skrzynkach modlitewnych mogło mieć także znaczenie wprowadzenie od 13 marca 2020 r. radykalnych ograniczeń w możliwości uczestnictwa w nabożeństwach sprawowanych w świątyniach i podejmowane próby transferowania różnych form praktyk religijnych do rzeczywistości wirtualnej. Mniej dostępne kościoły, obawy przed wychodzeniem z domu, ale też odkrywanie możliwości wykorzystania Internetu do komunikacji z sacrum mogły sprzyjać wpisom na internetowych skrzynkach intencji.

Definiując znaczenie modlitwy osobistej, K. Ladd i B. Spilka akcentowali takie atrybuty, które stanowią o jej unikalnej wartości dla badaczy życia społecznego: „modlitwa indywidualna i jej zamierzone cele często wydaje nam się czymś niepozornym, pozbawionym znaczącej formy i wielkich aspiracji. Będąc kwintesencją zachowań i aktów religijnych, modlitwa obejmuje sobą wirtualnie wszystkie ludzkie nadzieje i sprawy" (2014: 13). Używając tej nomenklatury, w dalszej części artykułu spróbujemy rozpoznać owe ,ludzkie nadzieje i sprawy” zapisane w internetowych modlitwach. Celem będzie identyfikacja postrzegania koronawirusa przez orantów, analiza uruchamianych procedur życiowej przemiany oraz rozpoznanie zakresu wyobrażonej wspólnoty w modlitwach wstawienniczych. Podjęta próba jakościowej eksploracji ma na celu wychwycenie charakterystycznych dla okresu pandemii wątków pojawiających się w zapisywanych modlitwach.

\section{„Żeby ludzkość przetrwała" - na progu apokalipsy}

Przywołując czeskie przysłowie - „zapomniałem o tym jak o śmierci" - T. Halik lapidarną, poetycką metaforą podkreśla w opisie

2 ogrod.augustianki.pl/intencje/?pageNum=16 (dostęp: 14.04.2020). Zachowano oryginalną pisownię wszystkich przytoczonych fragmentów wpisów.

${ }^{3}$ ogrod.augustianki.pl/intencje/?pageNum=16 (dostęp: 14.04.2020). 
kondycji współczesnego człowieka, że „nasza śmierć mieszka z nami w domu zapomnienia" (2017: 108). Wiele napisano już o separacji śmierci od konglomeratu ludzkich doświadczeń - delegitymizacji jej prawa do widocznej obecności, do naruszania ułudy nieśmiertelności. Obnażane przez C. Miłosza w jednym z wierszy zabiegi - „Każde z was dla niepoznaki/ wyprawia miny,/ żeby nikt nie zgadł, że/ lament w sobie nosimy" (2015: 1355) - w trakcie pandemii niespodziewanie poddane zostały nagłemu stress-testowi. Niosące przestrach komunikaty, suflowane przez media zwizualizowane opowieści (dość wspomnieć przerażający, ikoniczny obraz „transportów grozy” wywożących zwłoki ciężarówek z Bergamo), wyprowadziły śmierć z „domu zapomnienia” na sam środek ludzkiej agory. Nie tylko zresztą umierający ludzie, lecz także sam lockdown, niespodziewany i zdumiewający, brutalnie przypomniał o kruchości naszej egzystencji - o tym, „,co musi stać się niebawem” (Ap 1,1).

Wiele osób miało poczucie raptownego znalezienia się w sytuacji, która „zatrważa, wyrywa z letargu, każe ustanawiać granicę rozdzielającą/ rozdzierającą dotychczasowy świat i to, co ma przyjść, a co w swej nieobliczalności i katastrofizmie wymyka się poznaniu" (Kunce 2008: 260). Ślady tego przerażenia znajdujemy we wpisach:

Św. Rito Patronko od spraw trudnych i beznadziejnych w Panu Naszym i Najświętszej Panienki nadzieja za Twoim wstawiennictwem, w opiece nad nami nad naszym krajem i całym światem przed straszną epidemią, którą nie można zatrzymać, która jest dla nas ludzi wielką niewiadomą. Cóż mamy począć, przeżywamy strach o siebie i swoich bliskich. Błagam o wstawiennictwo w intencji nas ludzi, gdzie zderzyliśmy się z tak wielką niewiadomą i bezsilnością wobec nieznanego $0^{4}$.

Pandemia we wpisach to często zagrożenie o apokaliptycznym charakterze, niepodobnym do innych trudności, z którymi ludzkość musiała się mierzyć. Niektórzy oranci zdają się przerażeni i pełni obaw, że oto na ich oczach rozgrywa się zapowiadany w Apokalipsie koniec czasów, kiedy to ludzkość wyginie także przez śmierć „zadawaną morem” (Ap 6,8). Dla tych wyobrażeń charakterystyczne jest postrzeganie koronawirusa jako hegemona - epidemia zaczyna panować nad światem, przejmować go, rozciągać nad nim swoje zwierzchnictwo. Wyraźnie z części wpisów przebija się wojenna nomenklatura: nasz świat został zaatakowany przez wroga, który chce nad nim panować.

${ }^{4}$ ogrod.augustianki.pl/intencje/?pageNum=11 (dostęp: 14.04.2020). 
Ocal ludzkość przed koronawirusem! Analiza internetowych...

Z całego serca proszę o spokój na świecie, o bezpieczeństwo i o zatrzymanie pandemi wirusa, który zaatakował nasz świat ${ }^{5}$.

Jezu, Królu nasz i Panie, Matko Boźa, Królowo Korony Polskiej zakrólujcie nad tą pandemią i połóźcie jej kres. Prosimy z pokorą i ufnością

Proszę cię także o modlitwę za wszystkich ludzi na świecie aby ten wirus który panuje w końcu się skończył7.

Jednostkowy, anegdotyczny, ale ciekawy jest przypadek wpisu, którego autorka zdaje się rozszerzać to zagrożenie pan ow an i em wirusa na skalę przekraczającą doczesność i obejmującą także zaświaty. Trudno inaczej zinterpretować składane świętej życzenia zdrowia:

A tobie Św. Rito życzę abyś była zdrowa i była opatrznością dla innych oraz dla mnie w tych trudnych dla nas dniach. Amen ${ }^{8}$.

Poczucie niszczycielskiej mocy nieokiełznanego wirusa budzi przerażenie. Formułowane komunikaty modlitewne zawierają w sobie dramatyczne wołanie o ratunek czy ocalenie. Uniknięcie zarażenia i jego konsekwencji bywa rozpatrywane w kategoriach mirakularnych - aby przetrwać, konieczna zdaje się nadnaturalna interwencja:

Jezu bądź z nami, chroń nas! Proszę ocal ludzkość przed koronawirusem!9

Św Rito, Błagam dziś tak jak jeszcze nigdy Cię nie błagałam. Wstawiaj się u Pana za tą trudną sytuacją na świecie. Niech otworzą się oczy. Niech ta zaraza mija ${ }^{10}$

Święta Rito dziękuję za Twoje wstawiennictwo u Boga, błagam o cud ochrony przed wirusem. (...) Chroń cały świat, proszę, błagam - zabierz lęk $\mathrm{k}^{11}$

Św. Rito błagam o bezpieczeństwo w naszym kraju, błagam, aby pandemia nie zniszczyła ludzkości ${ }^{12}$

\footnotetext{
${ }^{5}$ ogrod.augustianki.pl/intencje/?pageNum=5 (dostęp: 14.04.2020).

${ }^{6}$ ogrod.augustianki.pl/intencje/?pageNum=7 (dostęp: 14.04.2020).

${ }^{7}$ ogrod.augustianki.pl/intencje/?pageNum=2 (dostęp: 14.04.2020).

${ }^{8}$ ogrod.augustianki.pl/intencje/?pageNum=7 (dostęp: 14.04.2020).

${ }^{9}$ skrzynkaintencji.pl/comment-page-2457/\#comments (dostęp: 14.04.2020).

${ }^{10}$ ogrod.augustianki.pl/intencje/?pageNum=7 (dostęp: 14.04.2020).

${ }^{11}$ ogrod.augustianki.pl/intencje/?pageNum=8 (dostęp: 7.05 .2020$)$.

${ }^{12}$ ogrod.augustianki.pl/intencje/?pageNum=7 (dostęp: 14.04.2020).
} 
Proszę błagam o modlitwę, by oddalić pandemię koronawirusa, by ludzkość przetrwała ${ }^{13}$.

Rozpatrywanie pandemii w kategoriach końca czasów może wyrastać z doświadczenia utraty ontologicznego poczucia bezpieczeństwa, globalnego wymiaru niepewności i zatrważającej świadomości bezradności czy nieadekwatności dotychczasowych narzędzi ochrony gatunku ludzkiego (takich jak medycyna, ale też na przykład zasoby militarne) względem nowej sytuacji. Uruchomienie apokaliptycznych pokładów wyobraźni można uznać za społecznie ważny i potencjalnie długotrwały skutek pandemii. Jak pisał niegdyś L. Kołakowski:

Przyswojenie sobie apokaliptycznego sposobu patrzenia na świat jest prawdopodobnie warunkiem, aby rasa ludzka mogła przeżyć i uniknąć apokalipsy samozagłady, wielkiego Końca, który sama sobie przygotowuje. Nasza ziemia nie jest wieczna, pewnego dnia przestanie istnieć. Egzystencja człowieka na jej powierzchni też nie jest wieczna, a każdy z nas żyje w cieniu swojej apokalipsy prywatnej, nieuniknionej i w gruncie rzeczy nieodległej: własnej śmierci (2014: 20).

Ten apokaliptyczny cień i doznanie wyjątkowości aktualnego czasu widoczne były w formułowanych modlitwach - także wówczas, gdy proszono „o drugą szansę dla nas dla wszystkich ludzi”"14. Świadomość sytuacji, w której się ludzkość (ale i każdy z orantów) znalazła, aktywowała również praktyczny wymiar reakcji, polegający na rozumieniu pandemii jako przynaglenia do przemiany postępowania: nienależnie od tego, czy rozumiano je jako Boże upomnienie czy „tylko” sprzyjającą okazję do własnego życiowego remanentu. Dla wydźwignięcia się z narcystycznych kolein i przekonania o własnej omnipotencji czasem nie trzeba wiele jak pisze papież Franciszek, „wystarczy potraktować swoją sytuację poważnie" (2016: 84). Doświadczenie pandemii mogło być istotnym zarzewiem, skłaniającym do przyjęcia takiej perspektywy. W dalszej części artykułu przyjrzymy się wpisom, które uznać można za świadectwa prób rekonstrukcji swojej życiowej postawy.

\footnotetext{
${ }^{13}$ ogrod.augustianki.pl/intencje/?pageNum=3 (dostęp: 7.05.2020).

${ }^{14}$ ogrod.augustianki.pl/intencje/?pageNum=5 (dostęp: 14.04.2020).
} 
Ocal ludzkość przed koronawirusem! Analiza internetowych...

\section{„Niech to będzie czas przemyślenia" - pandemia jako metanoia}

Epidemia jako zesłana przez Boga kara czy przynaglenie do zmiany dotychczasowego postępowania to częsty sposób interpretacji tego rodzaju spadających na ludzkość nieszczęść w historii. Miały one przypominać człowiekowi o jego grzesznej naturze i niegodnych występkach, których się dopuścił: ,nic to ieszcze, co cierpiemy; przećiwko temu, cośmy zasłużyli (...) piekielney szubienice godni grześnicy" - relacjonował epidemię dżumy w Krakowie franciszkanin M. Dziewulski (1720: A2). Takie ujmowanie łączyło się ze specyficzną wizją formowania ludzkiego życia przez Boga-lekarza, który zmuszony zostaje za pomocą dotkliwie bolesnej kuracji przywrócić zdrowie gatunkowi ludzkiemu: „winy i nieszczęśliwości wszystkie, nie są karą na zgubę, ale lekarstwem na poprawę, atoli i przestrzegaliśmy, że ten łaskawy Lekarz, gdy w nas poprawy nie dozna, będzie musiał przystąpić do przykrzejszej kuracji" (Sierakowski 1770, za: Jaszczuk 1994: 49).

Powyższe przeświadczenie miało też swoje istotne funkcjonalne znaczenie: przywracało poczucie - być może ograniczonej, ale jednak - kontroli nad niespodzianą zarazą i nadawało jej sens. W jakiejś mierze to od człowieka zaczynało zależeć, czy przetrwa zagrożenie. W opublikowanej tuż po wybuchu pandemii koronawirusa książce Wiara nie tylko $w$ czasach zarazy dominikanin T. Grabowski stawia tezę o zaniku tego wymiaru interpretacji: „W minionych epokach mówiono by (sic!), że Opatrzność dopuszcza zdarzenie krzyżujące ludzkie plany, ponieważ chce odwrócić ich serca od nadmiernego przywiązania do rzeczy przemijających. Nieszczęście było zatem wezwaniem do skruchy, podjęcia pokuty i nawrócenia. W umysłach współczesnych świat wymknął się z granic Boskiej Opatrzności, a w konsekwencji zjawiska w nim zachodzące utraciły duchowy sens" (2020: 12). Lektura skrzynek modlitewnych pokazuje jednak, że ciągle jest on obecny w indywidualnych wykładniach zarazy - co zilustrować można chociażby przywołanymi poniżej przykładami:

Dobry Boże, przebacz nam wszystkie grzechy i zatrzymaj pandemię koronawirusa $^{15}$

Św. Rito, proszę o wstawiennictwo w intencji naszej ojczyzny i całego świata, o pokonanie koronawirusa i nawrócenie wszystkich nas! ${ }^{16}$

\footnotetext{
${ }^{15}$ skrzynkaintencji.pl/comment-page-2471/\#comments (dostęp: 14.04.2020).

${ }^{16}$ ogrod.augustianki.pl/intencje/?pageNum=11 (dostęp: 14.04.2020).
} 
(...) niech obecny czas będzie czasem przemyślenia i przyjecia miłości Jezusa ${ }^{17}$.

Sporadycznie tylko zdarzały się także wpisy, w których bardzo wprost przywoływano zakres przewin mogących - wedle oranta - stanowić źródło Bożego gniewu:

Panie Boże przebacz Polakom i ludności Swiata grzechy aborcji, kłamstwa, rozwięzłości seksualnej, okaż nam swoje miłosierdzie i oddal zarazę korona wirusa z każdego kraju jeżeli jest to Twoją wolą ${ }^{18}$.

Interpretacja nieszczęścia pandemii i związanego z nią potencjalnego zagrożenia $\mathrm{w}$ paradoksalnych kategoriach łaski czy rozumienie wydarzeń jako wyjętego z normalnego biegu spraw kairosu skłaniającego i ponaglającego do radykalnej przemiany są możliwe wówczas, gdy uznamy te wydarzenia za przejaw osobliwej, niepojmowalnej ograniczonym ludzkim umysłem pedagogiki Boga. Takiej, o której pisała niegdyś S. Weil: „Bóg przyjmuje w stosunku do swoich przyjaciół pewien umowny język. Każde wydarzenie życia jest słowem tego języka. (...) Wspólnym sensem wszystkich tych słów jest: kocham cię" (1999: 181). W innym wypadku wizja koronawirusa jako elementu Bożego planu może jeszcze wzmagać poczucie niepokoju, który rozciągać się będzie już nie tylko na sprawy doczesne i ziemskie, lecz będzie miał wymiar eschatologiczny. W kolejnym podrozdziale przyjrzymy się takim wpisom, które - na różnych poziomach - są świadectwem niecierpliwości i psychicznej udręki wywołanych zagrożeniem.

\section{„Niech ten koszmar już się skończy” - o cierpliwość i spokój}

W jednej z modlitw zanotowanych podczas zarazy w XVIII wieku czytamy: „Zlituj się nad nami według Twojej obietnicy, rozkaż aniołowi zagłady i powiedz: Już dość" (Alkofer 1714, za: Górska 2010: 296). Charakterystyczny zwrot przynaglający do pilnego odsunięcia epidemii może stanowić świadectwo zniecierpliwienia przedłużającym się stanem zagrożenia. Niezależnie od tego czy zaraza jest rozumiana jako wynik Bożej pedagogiki, czy doszukuje się jej przyczyn w innym porządku - poczu-

\footnotetext{
${ }^{17}$ ogrod.augustianki.pl/intencje/?pageNum=5 (dostęp: 14.04.2020).

${ }^{18}$ skrzynkaintencji.pl/comment-page-2451/\#comments (dostęp: 14.04.2020).
} 
cie uporczywego milczenia Boga staje się frustrujące, człowiek zaczyna oskarżać Stwórcę o brak reakcji na bolesne i gorzkie perypetie ludzkiego losu, o nieczułość na ludzką biedę: „A Bóg się przygląda, jak człowiek umiera drugiemu człowiekowi”" (Canetti 2019: 25).

Zniecierpliwienie uznać można za jedną z dominant analizowanych wpisów. Wielokrotnie, na różny sposób oranci sygnalizują, że ,już dość”, ,już wystarczy”. Bóg powinien - „w końcu!” - zająć się tym problemem i przejąć panowanie nad światem, czyli unicestwić zagrożenie. Warto zauważyć, że owo zniecierpliwienie bardzo szybko pojawiło się w zapisach. Poniżej przykłady tekstów sporządzonych odpowiednio 13, 15 i 18 marca:

Żeby się już to skończylo. Jezu ufam Tobie ${ }^{19}$

Błagamy o modlitwę i wstawiennictwo o uproszenie łask za nas, aby epidemia już nie rozprzestrzeniała się, aby znaleźli w końcu sposób na wirusa, żebyśmy mogli walczyć z nim²

Dopomóż by ta pandemia koronawirusa jak najszybciej skończyła się i Polacy jak najszybciej wrócili do normalnego życia ${ }^{21}$.

We wpisach wielokrotnie pojawiały się sformułowania w rodzaju „oby ta zaraza skończyła się jak najszybciej”22 czy „aby już ten koszmar się skończył"23. Wyróżnić warto szczególnie jeden z takich wpisów, będący interesującym świadectwem sytuacji, gdy znajdujący się na skraju wytrzymałości człowiek zaczyna niemal dyktować Bogu właściwy sposób postępowania:

Wiem że Bóg daje nam ostrzeżenie przed tym abyśmy się opamiętali. Ale już dość, już koniec tych złych doświadczeń. Św. Rito dopomóż wstaw się za nami proszę. Tylko ty nam zostałaś, tylko ty możesz uprosić Pana Boga naszego. Jezu ufam Tobie, Jezu Ty się tym zajmij²4.

\footnotetext{
${ }^{19}$ ogrod.augustianki.pl/intencje/?pageNum=8 (dostęp: 14.04.2020).

${ }^{20}$ ogrod.augustianki.pl/intencje/?pageNum=10 (dostęp: 14.04.2020).

${ }^{21}$ ogrod.augustianki.pl/intencje/?pageNum=11 (dostęp: 14.04.2020).

${ }^{22} \mathrm{np}$. ogrod.augustianki.pl/intencje/?pageNum=2 (dostęp: 14.04.2020).

${ }^{23} \mathrm{np}$. ogrod.augustianki.pl/intencje/?pageNum=5 (dostęp: 14.04.2020).

${ }^{24}$ ogrod.augustianki.pl/intencje/?pageNum=7 (dostęp: 14.04.2020).
} 
Zmaganie się z psychicznymi niedogodnościami stanu pandemii mogło prowadzić do niecierpliwości czy wręcz frustracji wynikających z braku spodziewanej reakcji ze strony nadnaturalnych mocy. Pojawiały się jednak i takie wpisy, w których oranci nie tyle (czy przynajmniej: nie tylko) oczekiwali natychmiastowego unicestwienia przez Boga koronawirusa i przywrócenia światu właściwego porządku, co raczej prosili o potrzebne zasoby do zmagania się z tym problemem i jego konsekwencjami. Proszono o psychiczną wytrzymałość, spokój, opanowanie lęku czy odsunięcie depresyjnych myśli:

Św. Rito dopomóż mi w opanowaniu lęku i obaw przed wirusem, abym mogła spokojnie żyć i wypełniać swoje zadania, dodaj mi pewności $i^{25}$

Święta Rito błagam o zdrowie i bezpieczeństwo dla całej mojej rodziny.Chroń nas Święta Rito przed zarazą i strachem oraz daj nam więcej wiary i pokory ${ }^{26}$

Święta Rito, nie pozwól mi się załamać i chroń naszą rodzinę przed koronawirusem, szczególnie osoby najsłabsze z problemami zdrowotnymi. Pomóż, aby epidemię udało się jak najszybciej opanować ${ }^{27}$.

Idąc za myślą C. Geertza, wydźwięk powyższych wpisów możemy uznać za charakterystyczny dla religijnego spojrzenia na ludzkie dramaty i niedole: „Problem cierpienia, jako problem religijny, polega paradoksalnie nie na tym, jak uniknąć cierpienia, lecz na tym, jak cierpieć, jak uczynić fizyczny ból, osobiste nieszczęście, doczesną porażkę bądź bolesne doświadczanie umierania innych ludzi czymś co można przetrwać, czymś do wytrzymania, czymś - jak byśmy powiedzieli - możliwym do zniesienia" (1998: 52).

W zanoszonych prośbach o wytrwanie i przetrzymanie trudnego czasu znaleźć możemy również szerokie spektrum modlitw wstawienniczych za bliskich czy o właściwe relacje wewnątrzrodzinne w czasie pandemii.

Św. Rito proszę o wstawiennictwo, ratuj moją córkę przed strachem, że zarazi się koronawirusem, uproś uzdrowienie $\mathrm{z}$ chorób, by ukończyła studia i mogła znaleźć zatrudnienie, założyć rodzinę ${ }^{28}$.

${ }^{25}$ ogrod.augustianki.pl/intencje/?pageNum=4 (dostęp: 7.05.2020).

${ }^{26}$ ogrod.augustianki.pl/intencje/?pageNum=7 (dostęp: 14.04.2020).

${ }^{27}$ ogrod.augustianki.pl/intencje/?pageNum=8 (dostęp: 7.05.2020).

${ }^{28}$ ogrod.augustianki.pl/intencje/?pageNum=6 (dostęp: 7.05.2020). 
Ocal ludzkość przed koronawirusem! Analiza internetowych...

Proszę o dobrą atmosferę w domu by bliscy potrafili mnie zrozumieć że bardzo się lękam²9.

Bardziej wnikliwie wspólnotom obejmowanym wstawienniczymi wpisami modlitewnymi przez orantów przyjrzymy się w kolejnym podrozdziale.

\section{„Za wszystkich ludzi na świecie” - zakresy wyobrażonej wspólnoty}

Żyjemy w indywidualistycznej kulturze, suflującej poddanie się rygorom żmudnej samorealizacji - jej wytworem jest często narcystyczna jednostka, dla której „łaską staje się »bycie wybranym « przez siebie” (Jacyno 2007: 187). Jak pisze A. Mbembe, ,to epoka spod znaku tego, co nie łączy; tego, co nie jednoczy; tego, że wcale nie jesteśmy gotowi czymkolwiek się dzielić" (2018: 63). Gorzkie, być może nazbyt jednostronne diagnozy z pewnością wskazują na istotnie newralgiczny obecnie obszar: usytuowania człowieka $\mathrm{w}$ relacji $\mathrm{z}$ innymi. W tym kontekście uwidacznia się bardzo dobitnie jedna $\mathrm{z}$ potencjalnych konsekwencji modlitwy: $\mathrm{w}$ nawiązywanej $\mathrm{z}$ istotą wyższą komunikacji orant nie jest samotnym bytem, lecz wnosi w nią zwykle także gęstą sieć własnych społecznych powiązań. Przed Bogiem człowiek nigdy nie jest sam, zawsze jest z nim cały jego świat. W takim ujęciu nawet śmierć zdaje się doświadczeniem wspólnotowym - „W godzinę śmierci naszej” brzmią słowa najpopularniejszej maryjnej modlitwy.

Doświadczenie bycia z innymi na modlitwie jest być może szczególnie uchwytne w analizowanej tu jej formie - modlitwie indywidualnej, nieustalonej, której sam akt zapisu sprzyja uruchomieniu „wspólnotowej wyobraźni" i uświadomieniu sobie sieci powiązań z innymi osobami czy jakości rozmaitych relacji. To sytuacja, w której „,z Boga czyni się rozmówcę, Innego, wobec którego dokonuje się »eksterioryzacji podmiotu mówiącego« i próbuje zbudować wspólnotę, która pomoże przetrwać najdotkliwsze zrządzenia losu" (Kowalski 1994: 13). Ilustracją może być poniższa modlitwa:

Panie Jezu proszę Cię za wstawiennictwem Świętej Rity przez Niepokalane Serce Maryi o Wiarę, Nadzieję i Miłość dla ludzi, oraz o pracę zgodną z wolą Bożą, abyśmy mogli służyć każdy każdemu. Proszę o modlitwę za każdym kto naraża swoje życie ratując i pomagając innym w chorobie koronawirusa ${ }^{30}$.

\footnotetext{
${ }^{29}$ ogrod.augustianki.pl/intencje/?pageNum=8 (dostęp: 7.05.2020).

${ }^{30}$ ogrod.augustianki.pl/intencje/?pageNum=8 (dostęp: 7.05.2020).
} 
Pandemia koronawirusa i wprowadzone w ślad za nią obostrzenia w mobilności uwidoczniły nie tylko wagę ,łańcuchów dostaw” w zglobalizowanym świecie. Kwarantanna, zamknięcie granic, wymuszona izolacja poprzez swój globalny zasięg dosadnie wskazują także na współzależność ludzi - nawet na najbardziej rudymentarnym poziomie koniecznej troski o ochronę innych przed potencjalnym zarażeniem. Znajdujemy we wpisach ślady poczucia tej współodpowiedzialności:

Błagam by nikt nie zachorował, by osoba mi bliska postępowała rozsądnie i nie naraziła mnie i bliskich na zarażenie ${ }^{31}$

Proszę miej w opiece nasz cały naród, aby w tym trudnym dla nas czasie zagrożenia epidemią koronawirusa był rozsądny i zdyscyplinowany, aby ludzka bezmyślność nie miała szans w walce z tą chorobą, aby młodzi ludzie dbali o starszych, aby babcie i dziadkowie byli bezpieczni z dala od maluchów ${ }^{32}$.

Analizując pobrane ze skrzynek intencji zapisy możemy wyróżnić przynajmniej kilka zakresów obejmowanej nimi wspólnoty - od osób najbliższych aż po cały świat. Jak wskazują także inne badania tego rodzaju zapisów (np. Cekiera 2016), najbardziej oczywistą wspólnotą, która pojawia się w modlitwach, jest rodzina. Ze zrozumiałych powodów w dobie koronawirusa prośby dotyczyły często starszego pokolenia:

Kochany Sw. Michale Archaniele, prosimy Cie pokornie o obrone naszych rodzicow przed koronawirusem, szczególnie mojego taty, Czeslawa, który jest po chemioterapii ${ }^{33}$

Święta Rito proszę miej pod swoją opieką mamę Irenę, aby mogła wyjść z domu i bezpiecznie pójść na wizyty do lekarzy specjalistów, żeby nic złego się nie stało i nie zaraziła się koronawirusem ${ }^{34}$.

W modlitwach wstawienniczych przywoływano także znajomych (wspólnota towarzyska) czy - co ciekawe - zakażone osoby z pobliskich terenów (wspólnota geograficzna):

${ }^{31}$ ogrod.augustianki.pl/intencje/?pageNum=7 (dostęp: 14.04.2020).

${ }^{32}$ ogrod.augustianki.pl/intencje/?pageNum=11 (dostęp: 14.04.2020).

${ }^{33} \mathrm{kjb} 24 . \mathrm{pl} / \mathrm{ksiega}$-intencji/?pageNum=2 (dostęp: 14.04).

${ }^{34}$ ogrod.augustianki.pl/intencje/?pageNum=4 (dostęp: 7.05.2020). 
Ocal ludzkość przed koronawirusem! Analiza internetowych...

Bardzo proszę o modlitwę w intencji Antona i jego rodziny, jego tata Iwan leży chory zarażony wirusem w szpitalu, stan poważny ${ }^{35}$

Polecam Twej opiece zakażonych mieszkańców gminy Gdów - proszę o zdrowie dla nich oraz o opanowanie ognisk choroby, aby wirus nie rozprzestrzeniał się $e^{36}$.

Charakterystyczne dla sytuacji są także modlitwy, którymi obejmuje się szczególnie ważne z punktu widzenia walki z pandemią i jej skutkami profesje: lekarzy, naukowców, ale też rządzących czy sprzedawców.

PANIE BOŻE proszę Cię chroń lekarzy, całą służbę medyczną i wszystkich, którzy niosą pomoc chorym i zatrzymaj pandemię coronawirusa ${ }^{37}$

Proszę święty Michale Archaniele, prowadz badaczy by wynaleźli szczepionkę pw koronawirusowi ${ }^{38}$

Proszę o mądrość dla naukowców i rządzących, którzy będą łagodzić restrykcje, proszę, aby robili to $\mathrm{z}$ głową

Modlę się za lekarzy, kasjerki, sprzedawców, którzy najbardziej są narażeni ${ }^{40}$.

Sytuacja globalnego zagrożenia sprokurowała także wiele wpisów, w których odnoszono się do wspólnot najszerzej rozumianych: ojczyzny i rodaków czy po prostu ludzkości. Konstruowane w taki sposób modlitwy mogą być świadectwem międzyludzkiej solidarności w obliczu zagrożenia.

Niech Zmartwychwstały Chrystus ochroni moją rodzinę, ojczyznę i cały Świat przed chorobami, wirusami, zarazami i wojną ${ }^{41}$

Proszę cię bardzo w ten szczególny czas Wielkanocy o modlitwę za wszystkich ludzi na świecie, aby ten wirus zniknął. Aby w końcu ludzie byli bezpieczni i zdrowi ${ }^{42}$

\footnotetext{
${ }^{35}$ skrzynkaintencji.pl/comment-page-2492/\#comments (dostęp: 7.05.2020).

${ }^{36}$ ogrod.augustianki.pl/intencje/?pageNum=4 (dostęp: 7.05.2020).

${ }^{37}$ skrzynkaintencji.pl/comment-page-2478/\#comments (dostęp: 7.05.2020).

${ }^{38} \mathrm{kjb24.pl/ksiega-intencji/?pageNum=2} \mathrm{(dostęp:} \mathrm{7.05.2020).}$

${ }^{39}$ ogrod.augustianki.pl/intencje/?pageNum=8 (dostęp: 7.05.2020).

${ }^{40}$ ogrod.augustianki.pl/intencje/?pageNum=7 (dostęp: 14.04.2020).

${ }^{41}$ ogrod.augustianki.pl/intencje/?pageNum=8 (dostęp: 7.05.2020).

${ }^{42}$ ogrod.augustianki.pl/intencje/?pageNum=2 (dostęp: 14.04.2020).
} 
Święta Rito proszę o zdrowie dla naszej rodziny, pomóż proszę ludziom na całym świecie, aby ustala epidemia, wspieraj osoby ratujące życie chorym, nie opuszczaj nas uproś u Jezusa litość nad całym światem ${ }^{43}$.

Patrząc na oczekującą zapisu stronę wotywnej księgi czy okno internetowej skrzynki intencji, człowiek dokonuje swoistej rekapitulacji. Definiuje własną życiową sytuację, ale - skoro jesteśmy istotami społecznymi - w oczywisty sposób prześwietla również relacje z bliskimi czy stosunek do wspólnot, których czuje się członkiem. Sam akt zapisu prowokuje więc do obejmowania myślą innych, wychodzenia poza samego siebie; samo formułowanie prośby może stać się mechanizmem zmiany. Pozornie błahy gest może mieć dla oranta i jego społecznych światów dalekosiężne konsekwencje: rozszerzyć subiektywną perspektywę, stworzyć przestrzeń solidarności i poczucia braterstwa.

\section{Podsumowanie}

Zaproponowana powyżej interpretacja wpisów ze skrzynek intencji jest jednym $\mathrm{z}$ możliwych sposobów rozumienia pandemii $\mathrm{w}$ religijnym kluczu. Z racji badań jakościowych - pomijających ilościowy wymiar poszczególnych zapisów - artykuł miał na celu raczej zwrócenie uwagi na pewne zaobserwowane interesujące wątki niż kompletną, przekrojową eksplorację tej formy religijnych praktyk. Apokaliptyczna perspektywa zagrożenia, zniecierpliwienie i niepokój, ale także odczytywanie pandemii jako znaku, kierowanego do ludzkości komunikatu - czyli znane także z historii reakcje na tego rodzaju zdarzenia - ciągle są znacząco obecne w religijnym myśleniu o koronawirusie. Wywołują one różne reakcje - od przerażenia i buntu, przez deklarowaną przemianę własnego życia, aż po pokorne prośby o siły do mierzenia się z niebezpieczeństwami. Wszystkie one są jednak wspólnym świadectwem żywotności religijnego uniwersum w nadawaniu ,zobiektywizowanych społecznie i subiektywnie rzeczywistych" znaczeń oraz integrowaniu granicznych sytuacji w życiu człowieka z jego całościową biografią (Świątkiewicz 2010: 266). Interesującą kwestią wydaje się także bardzo szeroki zakres próśb wstawienniczych, wychodzący poza to, co bliskie i lokalne w stronę szerszych wspólnot czy po prostu całej ludzkości. Tak interpretowane wpisy stają się świadectwem poczucia globalnej solidarności w mierzeniu się z nieznanym.

${ }^{43}$ ogrod.augustianki.pl/intencje/?pageNum=4 (dostęp: 14.04.2020). 
Ocal ludzkość przed koronawirusem! Analiza internetowych...

Zarzewiem wpisu do skrzynki intencji jest wiara lub przynajmniej otwarcie na mirakularną rzeczywistość. Podczas lektury wielu wpisów można odnieść wrażenie, że c ud już się wydarzył - jeśli rozumieć to pojęcie nie jako „zawieszenie praw przyrody”, ale wykroczenie poza to, co wydaje się w danej sytuacji oczywiste i spodziewane (Halik 2010: 185). Zaduma nad pustym oknem internetowej skrzynki modlitewnej może prowadzić do nieoczywistego rozbudzenia w sobie wrażliwości na potrzeby innych czy niespodziewanego odkrycia zakresu ludzkiej współzależności. I w tym, nawet najbardziej pozbawionym sakralnych odniesień, rozumieniu sprzyjać metanoi - przemianie myślenia, która ostatecznie stworzyć może szansę na uniknięcie zagłady.

\section{BIBLIOGRAFIA:}

Bątkiewicz-Brożek, J. (2017). Jezu, Ty się tym zajmij! Komu Jezus zostawit tę potężna modlitwę?. Pozyskano z pl.aleteia.org/2017/06/29/jezu-ty-sie-tymzajmij-komu-jezus-zostawil-te-potezna-modlitwe/ (dostęp: 28.042020).

Biblia, [online:] https://biblia.deon.pl/.

Canetti, E. (2019). Księga przeciwko śmierci (tłum. M. Przybyłowska). Sejny: Pogranicze.

Cekiera, R. (2016). Zgryzoty i nadzieje. Socjologiczna analiza wpisów do ksiag wotywnych w kaplicy św. Wendelina w Rudzicy. Rudzica: TMR.

Czarnowski, S. (1939). Podziat przestrzeni i jej ograniczenie w religii i magii. Cieszyn, Warszawa: Nasza Księgarnia.

Dziewulski, M. (1720). Prezerwatywa od powietrza morowego. Kraków: Druk: Jakoba Mattaszkiewicza. Pozyskano z https:/www.wbc.poznan.pl/dlibra/ publication/41672/edition/58589/content

Franciszek (2016). Miłosierdzie to imię Boga. Rozmowa z Andrea Torniellim (thum. J. Ganobis). Kraków: Znak.

Geertz, C. (1998). Religia jako system kulturowy. W: W. Piwowarski (red.), Socjologia religii. Antologia tekstów (s. 48-79). Kraków: Nomos.

Giddens, A. (2002). Nowoczesność i tożsamość. „Ja” i spoleczeństwo w epoce późnej nowoczesności (tłum. A. Szulżycka). Warszawa: PWN.

Górska, L. (2010). Dżuma - epidemia duszy i ciała? Sposoby zwalczania dżumy w nowożytnym Gdańsku. Studia Humanistyczne Wydziału Farmaceutycznego Akademii Medycznej we Wroctawiu, 3, 279-309.

Grabowski, T. (2020). Wiara nie tylko w czasach zarazy. Poznań: W drodze. 
Halik, T. (2010). Dotknij ran (tłum. A. Babuchowski). Kraków: Znak.

Halik, T. (2017). Z hipotezą Boga - albo bez niej. W: A. Grün, T. Halik, W. Nonhoff (red.), Bóg zagubiony. Wiara w objęciach niewiary (s. 83-111). Warszawa: WAM.

Jacyno, M. (2007). Kultura indywidualizmu. Warszawa: PWN.

Jaszczuk, M. (1994). Dżuma w polskim piśmiennictwie w XVIII wieku. Medycyna Nowożytna, 1-2, 31-60.

Kapusta, A., Poźniak, A. (2011). Intencje z Rybna. Teksty (post)rytualnej ekspresji ,ja” biograficznego. Studia Kulturowe. W kręgu teorii kultury, miejsca i spektaklu, 2, 56-69.

Kołakowski, L. (2014). Jezus ośmieszony. Esej apologetyczny i sceptyczny (thum. D. Zańko). Kraków: Znak.

Kowalski, P. (1993). Samotność i wspólnota. Inskrypcje w przestrzeniach wspótczesnego życia. Opole: Wyższa Szkoła Pedagogiczna Instytut Filologii Polskiej.

Kowalski, P. (1994). Prośba do Pana Boga. Rzecz o gestach wotywnych. Wrocław: Towarzystwo Przyjaciół Polonistyki Wrocławskiej.

Kowalski, P. (2007). Kultura magiczna. Omen, przesąd, znaczenie. Warszawa: PWN.

Kunce, A. (2008). Antropologia punktów. Rozważania przy tekstach Ryszarda Kapuścińskiego. Katowice: Wydawnictwo Uniwersytetu Śląskiego.

Ladd, K.L., Spilka, B. (2014). Psychologia modlitwy. Spojrzenie naukowe (thum. M. Chojnacki). Kraków: Wydawnictwo WAM.

Luckmann, T. (1996). Niewidzialna religia. Problem religii we współczesnym społeczeństwie (tłum. L. Bluszcz). Kraków: NOMOS.

Makuchowska, M. (1998). Modlitwa jako gatunek języka religijnego. Opole: Instytut Filologii Polskiej Uniwersytetu Opolskiego.

Marai, S. (2017). Dziennik, 1949-1956 (tłum. T. Worowska). Warszawa: Czytelnik.

Mariański, J. (2013). Sens życia, wartości, religia. Studium socjologiczne. Lublin: Wydawnictwo KUL.

Mbembe, A. (2010). Polityka wrogości. Nekropolityka (tłum. U. Kropiwiec, K. Bojarska). Kraków: Wydawnictwo Karakter.

Miłosz, C. (2015). Wiersze wszystkie. Kraków: Znak.

Rozenfeld, K. (1920). Walka z epidemią grypy, jej najważniejsze zadania i środki. Gazeta Lekarska, 12-13, 122-136.

Tokarska-Bakir, J. (2000). Obraz osobliwy. Hermeneutyczna lektura źródet etnograficznych. Wielkie opowieści. Warszawa: Universitas. 
Ocal ludzkość przed koronawirusem! Analiza internetowych...

Weil, S. (1999). Świadomość nadprzyrodzona (tłum. A. Olędzka-Frybesowa). Warszawa: Instytut Wydawniczy PAX.

Wilkinson, M., Althouse, P. (2015). The Embodiment of Prayer in Charismatic Christianity. W: G. Giordan, L. Woodhead (red.), A Sociology of Prayer (s. 153-167). Farnham: Ashgate Publishing Limited.

Wojtak, M. (2000). Modlitwa jako gatunek wypowiedzi. W: W. Książek-Bryłowa, H. Duda (red.), Język polski-Współczesność-Historia (s. 133-141). Lublin: Wydawnictwo UMCS. 